العـــــــد السابع والثلاثون

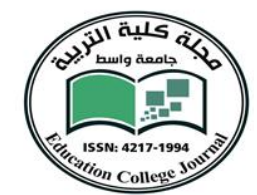

جامعة واسط

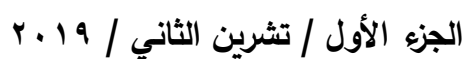

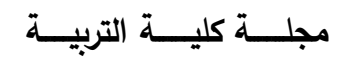

\title{
جماليات توظيف الوحدات الزخرفية والحرف العربي في تصاميم اقمشة الازياء النسائية
}

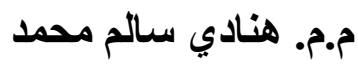

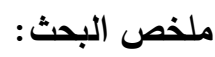

تعد الفنون بتتوعاتها إحدى وسائل التعبير المهمة عن الحاجات والاهتمامات الإنسانية نتيجة لحاجة الإنسان الروحية والنفسية إلى الجمال، لذلك فمنذ أن بدأ الإنسان يتلمس معنى الجمال وصوره في الكون بشكل عام والبيئة المحيطة به بشكل خاص وإحساسه الذاتي به ومن ثم أخذ يعكسه بصورة منتوج جمالي، فقد كان رجل الكهف مثلاً يعبر عن الأشكال التي يراها ويحاول تقليدها بواسطة الرسم بأي من طرائقه البدائية التي تعبر عن الأحاسيس والأفكار .

اذ يهدف البحث الحالي إلى التعرف على كيفية توظيف الوحدات الزخرفية الاسلامية والخط

العربي في تصاميم الاقمشة النسائية وتبيان جماليتها.

اعتمدت الباحثة المنهج الوصفي التحليلي في تصميم اجراءات بحثها كونها اكثر المناهج العلمية ملائمة لتحقيق هدف البحث، اذ يتضمن البحث الحالي دراسة وتحليل تصاميم اقمشة النساء ضمن الواقع الميداني والاستطلاعي التي حصلت من خلالها الباحثة على مجموعة تصاميم تم عرضها في الاسواق المحلية لمدينة بغداد لغرض تحقيق هدف البحث، اذ تم حصر (YOO) أنموذجاً تصميمياً لاقمشة الازياء النسائية، فقد تم اختيار (ع) نماذج سائدة في الاسواق المحلية وهي من هن

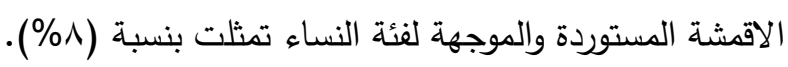
فقد قامت الباحثة بناء استمارة تحليل محتوى نماذج العينة بناءً على ما اسفر عنه الاطار النظري من مؤشرات متضمنة محاور اصبحت فقرات اساسية خاصة بتصاميم اقشة الازياء النسائية

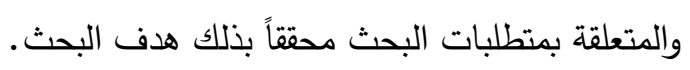

\section{وقد خرج البحث بمجموعة من الاستتتاجات اهمها:}

1-ان الوحدات الزخرفية المستخدمة في تصميم اقشة ملابس والازياء الموجه للمراة لها دور بارز في هي اعطاء الصفات المظهرية للقماش كونها تضفى نوع من التنوع الجمالي والتعبيري لمفردات التصميم. ז-ان الالوان التي وظفها مصمم الاقمشة لعبت دوراً اساسياً في ابراز جمالية الوحدات الزخرفية والهندسية التصميمية للقماش مما حققت نوعاً من الابعاد الرمزية والجمالية والوظيفية. 


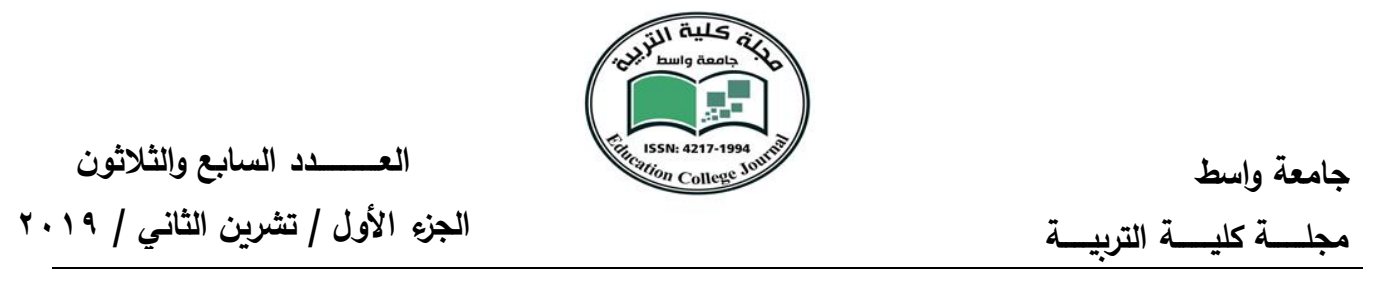

The Aesthetic of Employing the Ornamental Units and the Arabic Letter in the Design of the Women's Fashion Clothes

\title{
Assist. of Lect. Hanadi Salim Muhammed
}

\begin{abstract}
The arts in its varieties consider one of the important expression means about the human needs and interests as a result of spiritual and psychological human needs to the beauty. Since the human started inspired the meaning of the beauty and its images in the universe in general and the surrounding environment in special and the subject sense in it, then began reflex it as an aesthetic production. As an example; the man of cave was expressed about the things see them and tried to imitate them by drawing in any of his primitive methods which expressed on the senses and thoughts.
\end{abstract}

The research aims to realize the means of employing the Islamic ornamental units and Arabic letter in design of the women's clothes and clearing on their beauty. The researcher depended on the descriptive analyzing method in creating the research procedures because it is the most scientific method suitable to achieve the aim of the research. The current research comprised on studying and analyzing the designs of women's clothes in the field and exploratory reality that the researcher obtained through them some group of designs were presented on the public markets of Baghdad in order to achieve the aim of the study. So, it is surveyed (52) samples of designs for women's fashion clothing and selected (4) samples are common in the public markets from the imported clothes target the women group represented in percentage of $(8 \%)$.

The researcher designed the application of analyzing including the samples depending on the hypothetical section from indications comprised on the themes then became basic paragraphs concerned in the clothing design of women's fashion and they connected with the research to fulfillment to achieve the aim of the research.

The research concluded some results such as: 
العـــــــد السابع والثلاثون

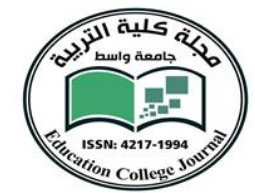

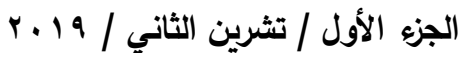

جامعة واسط

مجلـــة كليـــــة التربيـــة

1. The units of ornaments used in design of the women's clothing have an apparent role in giving the out qualities of cloth because they give kind of aesthetic and expressive varieties for the parts of the design.

2. The colours are employed by the cloth's designer played an essential role in presenting the beauty of the ornamental and geometrical designs to the cloth that achieved kind of symbolic, aesthetic, and functional dimensions.

الفصل الاول : مشكلة البحث:

يتجلى الفن الإسلامي في صور متنوعة لله مرجعيات واصول امتدت عبر الحضارات

الانسانية، بالرغم من تجديداته الكثيرة في موضوعاته وفي تركيبها، فكل خصيصة من خصائص رسوم الفن الإسلامي تطوي بثناياها رؤية عميقة إزاء خالق الكون والكون نفسه والإنسان، وهذا المضمون الروحي نابع من التصورات الأساسية للفنان المسلم تجاه تلك المفاهيم. فما اكتسبته بنية الوحدة الزخرفية في الفن الإسلامي من قيم جمالية وأبعاد مهمة مفاهيمية فكرية وروحية جعلتها السمة المميزة لهذا الفن لاسيما أنها جزءٌ مهماً من أجزاء التكوين الفني، لذا فان إتقانه من قبل الفنان المسلم يبعث المتلقي على التأمل والنظر فيه لاستخراج مكنوناته الدلالية والجمالية والوجدانية، اذ يمثل الجمال وعملية الإحساس به واحدا من السمات التي ينفرد بها الفنان المسلم دون سواه من الخلائق، ويمكن الاستدلال عليه حينما نمعن النظر فيما أنجز عبر أطوار الحضارة الإنسانية والذي يكشف عن اطراد الوعي والتلاحم مع مظاهر الطبيعة. ففي موضوع الوحدات الزخرفية والحرف العربي كتكوين جمالي يمكن ان يعتمده المصدم في تصميم نتاجاته التصميمية ومنها تصاميم الاقمشة، فبواسطة بنية تكوين الوحدات الزخرفية المتتوعة، لتونية يستطيع المصدم التعبير عن رؤية الظاهر والمستتر من خلال وحداته التصميمية التي تتميز بخصائص بنائية مهمة في تتظيم الأشكال والفضاء والسطوح، فضلاً عن ان هذه الوحدات البنائية تستند إلى وحدة فكرية.

لذلك يمكن ان تظهر هذه السمات في الفن العربي الإسلامي بشكل عام وتوظيف الوحدات الزخرفية والحرف العربي في النتاجات المعاصرة بشكل خاص عن وجود نمط من التفكير الجمالي الذي يقف ورائها، وتفرده في التذوق الجمالي ضمن الاسس والقواعد الخطية والزخرفية واخراجها 
العـــــــد السابع والثلاثون

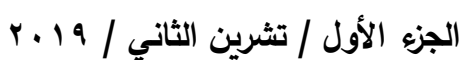

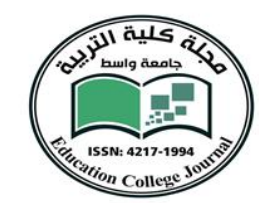

جامعة واسط

مجلـــة كليـــــة التربيــــة

بتكوينات وتراكيب متتوعة، وبما أن هذِه المساحة قليلة الدراسة بشكلها الفني الاستقرائي الذي يكشف الأبعاد والمديات الإبداعية للقيمة الجمالية بثكل تنظيري، لذا اجرت الباحثة دراسة استطلاعية في ميدان فن الخط العربي والزخرفة يطرح مشكلة البحث الحالي بالتساؤلات الاتية :-

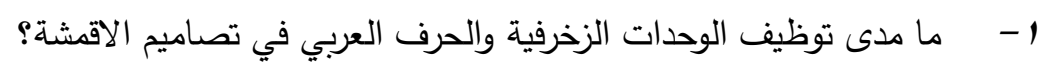
r - ما السمات الجمالية للخط العربي في الفن الاسلامي؟ r- ما العلاقات الجمالية في حروف خط الثلث؟

كل هذه الأسئلة ولات أساساً لمشكلة حقيقية للبحث كون الوحدة الزخرفية في رسوم الواسطي لها خاصية فنية متميزة لكنها بقيت ضمن نطاق الوصف العام دون التعمق الأكاديمي، وأن للوحدات الزخرفية مدلولات عقائدية وفكرية وروحية وجمالية لم تبحث سابقاً؟ وتأسيساً على ذلك تمكنت الباحثة من حصر مشكلة البحث في كيفية توظيف الوحدات الزخرفية والحرف العربي في تصاميم اقمشة الازياء النسائية والوقوف على مستوى جمالية هذا التكوين في الاقمشة.

\section{أهمية البحث والحاجة إليه :}

ا ـ تسليط الضوء على منطقة مهمة وغنية في الفن العربي الإسلامي من خلال تقصي ظهور المفاهيم الفكرية والجمالية للوحدات الزخرفية والخط العربي بوصفها مفردات مستلة من التراث الحضاري الحئي للفن الاسلامي وكيفية توظيفها في تصاميم اقمشة الملابس النسائية بصوره جمالية وفنية تسهح في الإثراء المعرفي والعلمي للمهتمين بهذا الموضوع..

ץ.بعد البحث الحالي منجزاً معرفياً في إرساء أسس علمية للدارسين والمختصين في مجال تصميم الاقشة بشكل عام والنسائية بشكل خاص في كيفية توظيف الوحدات الزخرفية والخط العربي في هذا النوع من التصاميم. 
العـــــــد السابع والثلاثون

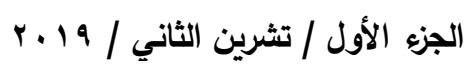

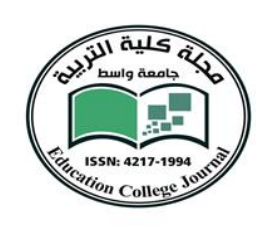

جامعة واسط

هدف البحث: يهدف البحث الحالي إلى:

التعرف على كيفية توظيف الوحدات الزخرفية الاسلامية والخط العربي في تصاميم الاقمشة

النسائية وتبيان جماليتها.

حدود البحث :-يقتصر البحث الحالي على :

عملية توظيف الوحدات الزخرفية والحرف العربي في تصاميم اقمشة الازياء النسائية.

تحديد المصطلحات: عرفت الباحثة المصطلحات التي وردت في عنوان البحث اجرائياً:

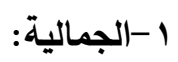

هي قيمة مرتبطة بالغريزة والعاطفة والشعور الإيجابي نحو الأشياء، فهي الحسن والنضرة والكمال، بما يتتاسب فعلياً مع قيمة الثيء وحسنه، ويمكن الاحساس بها من خلال التوظيف الفعال للوحدات الزخرفية والحرف العربي في تصاميم اقمشة الازياء النسائية.

\section{r ب التوظيف: - r}

هو عمليه استثار الوحدات الزخرفية والحرف العربي ومدى الإفادة منه في تصاميم الاقمشة النسائية.

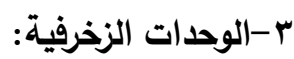

تتكون الوحدة الزخرفية من مجموعة نقاط وخطوط وأشكال هندسية ورسوم لحيوانات او نباتات او توظيف الحرف العربي بشكل متداخل ومتناسق ومتوازن فيما بينها عن طريق التكرار والتشعب والتناظر والتماثل والتعاقب لتعطي شكلا جميلا وتُستعمل في تنزين المباني والأواني والمالابس والجوامع والكنائس والمدافن والنقود والعملات والقصور وبعض أعلام الدول ... وغيرها.



أما التعريف الإجرائي لـ" توظيف الحرف " فهو : (عملية استخدام الحرف العربي في تصاميم الاقمشة النسائية بعد اجراء التحوير المناسب عليه والافادة منه في تصاميم الاقمشة النسائية. 
العـــــــد السابع وإلثلاثون

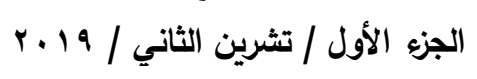

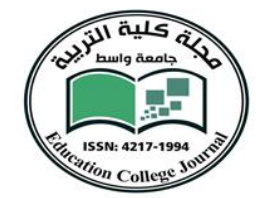

جامعة واسط

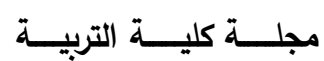

\section{الفصل الثاني - الاطار النظري \\ جمالية الوحدات الزخرفية وإلحرف العربي في التصميدم}

يقترن فن الخط بالزخرفة العربية (أرابيسك) حيث يستعمل لتزيين المساجد والقصور ، كما أنه

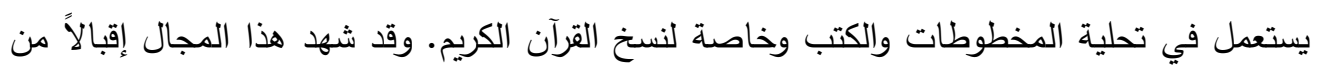

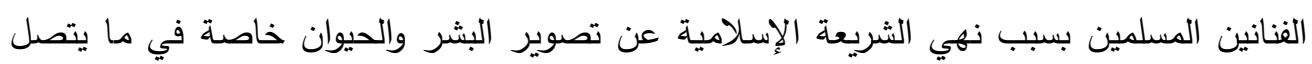





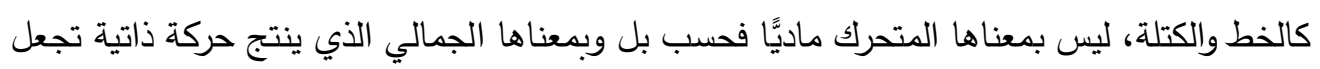
الخط يتهادى في رونق جمالي مستقل عن مضامينه ومرتبط معها في آن واحد.

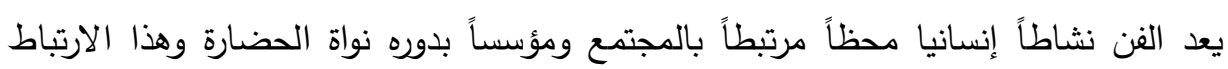

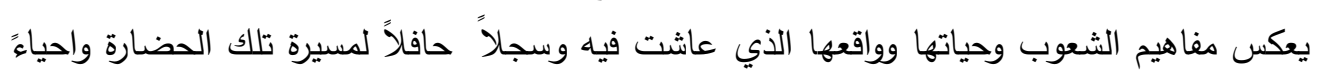

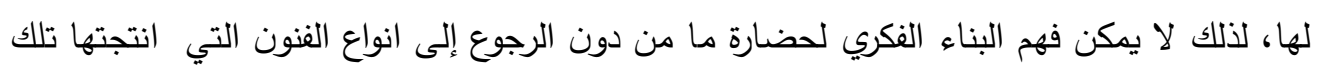

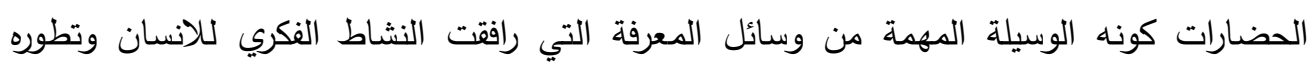
الزماني والمكاني.

لذلك يقترن ظهور الفن بمولد الإنسان على وفق حاجاته ومتطلباته اليومية كونه لم يكن فناً

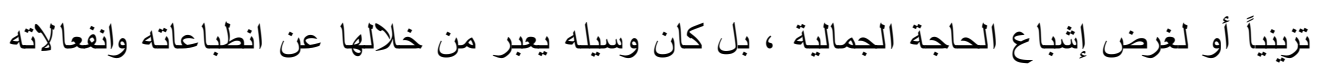

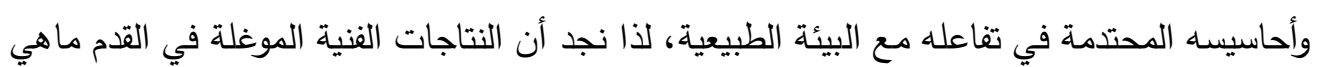

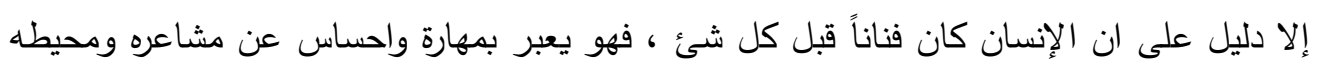
وتجاربه.

اذ يشير (هوينغ) بهذا الصدد "لفهم دلاله العمل الفني ومحركاته الفكرية عبر اداوره الحضارية

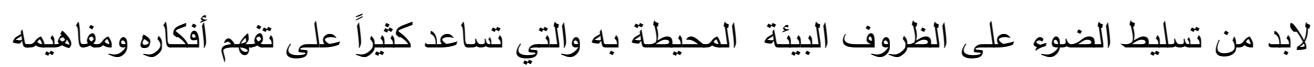

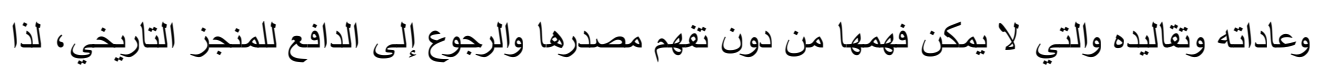

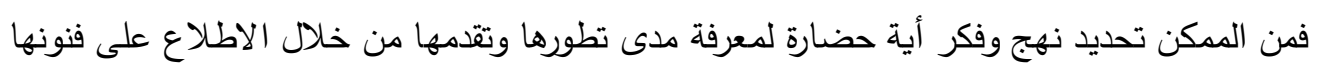

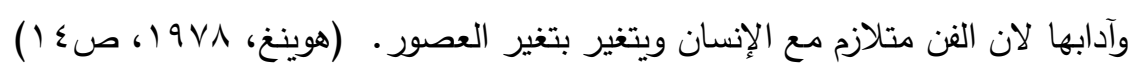


العـــــــد السابع والثلاثون

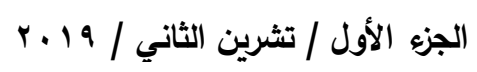

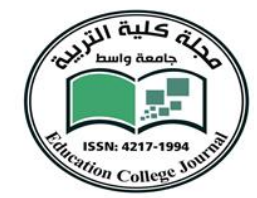

جامعة واسط مجلـــة كليـــة التربيــة

وقد اختلفت طرائق التعبير ووسائله لاى الإنسان بالأشكال والألوان والخطوط ، فكان للإحداث والظروف التي عاشها من جهة والتطور الحضاري من جهة اخرى، اثر في خلق تلك الوسائل وتنوعها.

بناءً على ذلك ترى (الباحثة) أن الفن يعد نشاطاً إنسانيا واجتماعياً وثقافياً ويتصف بصفات

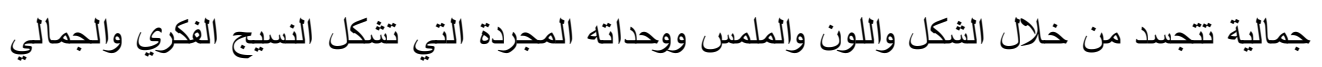

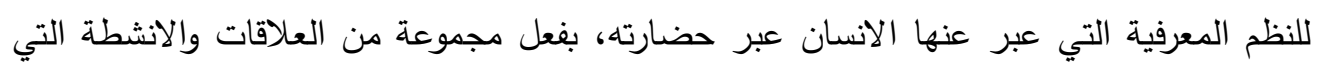

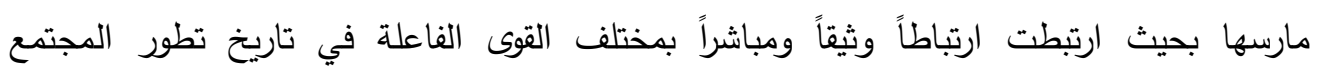
الحضاري، لهذا عند دراسة وفهم البناء الفكري لاي مجتمع لابد من الرجوع الى موروثه ونتاجاتهاته الفنية عبر الحضارة. - مباري

فالتواصل مع الموروث ليس بالأمر اليسير لدى الفنان او المصمم المعاصر على أساس

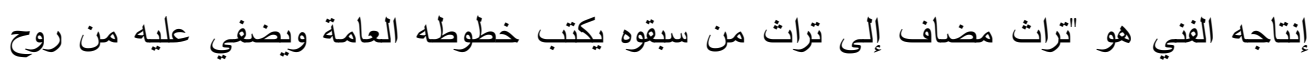

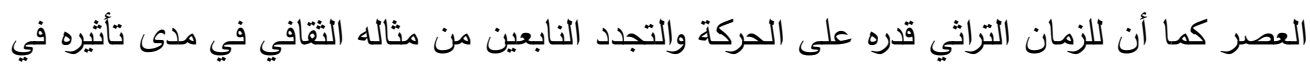
حيلة وعصره واستمرار ذلك في الأجيال والعصور التلاحقة".

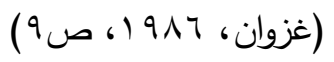

اذ يمكن مشاهدة الكثير من النتاجات الفنية العراقية المعاصرة ومنها تصاميم الاقمشة الموجه

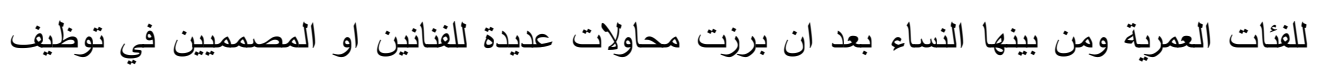

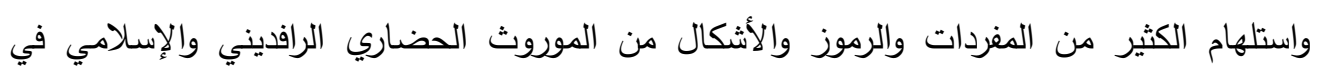
تصاميم المنتج الموجه للفئات العمرية.

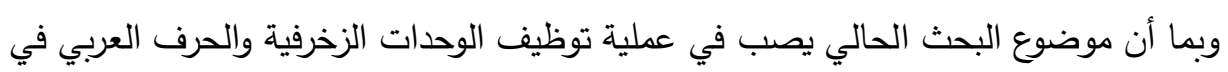

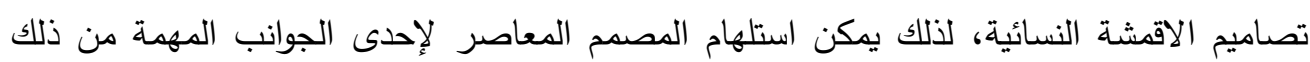

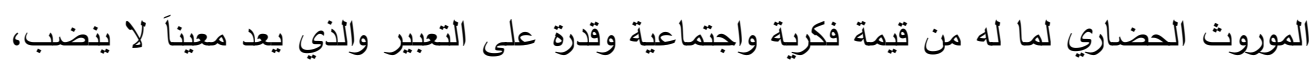

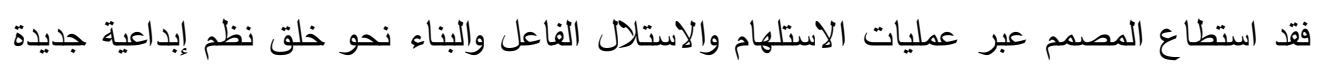

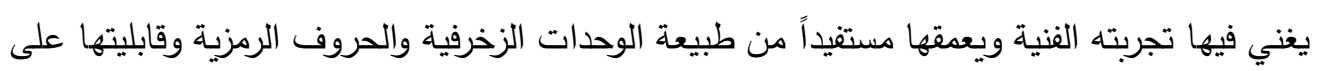

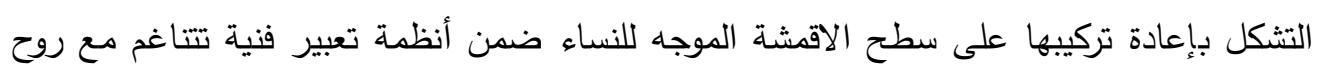

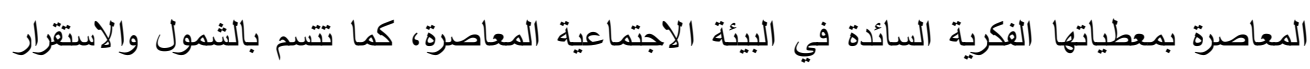

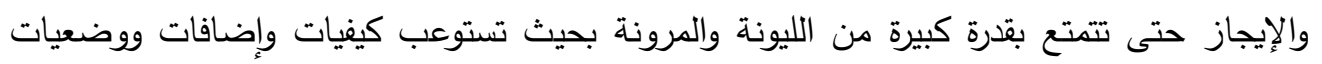


العـــــــد السابع وإلثلاثون

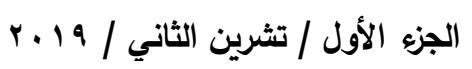

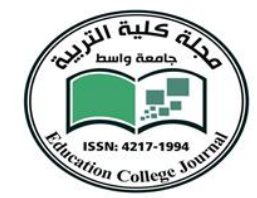

جامعة واسط

مجلـــة كليـــة التربيــة

جديدة هي من سمات الإنسان المعاصر من دون أن تفقد دلالاتها ولا تعبر عن عكس الكثير من هموم العصر وملابساته.

كما أن دور المصمم في بحثه المتجدد عن مفردات تصاميم الاقمشة بانواعها الذي يؤمن

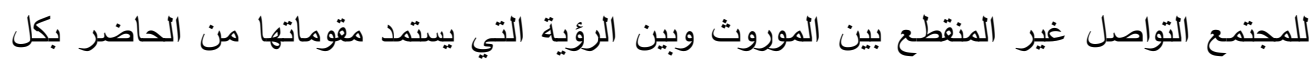

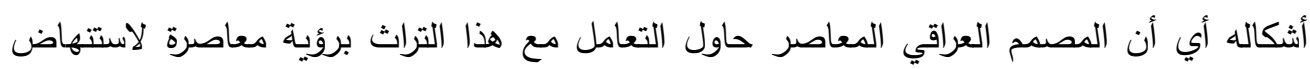

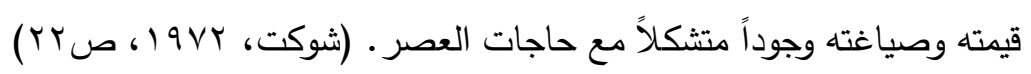

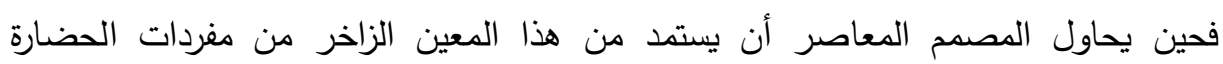

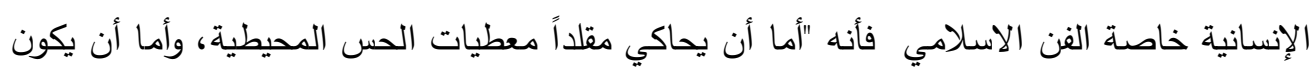

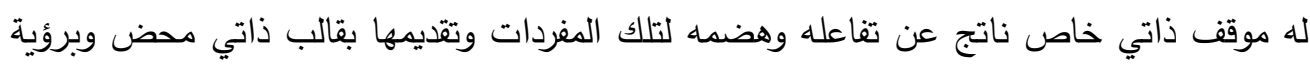

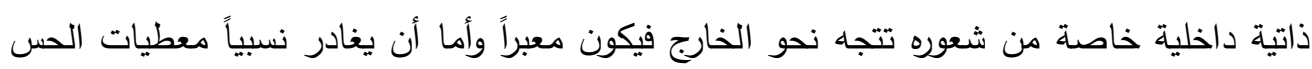

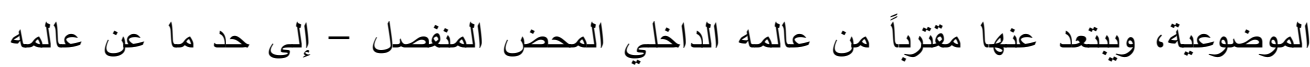

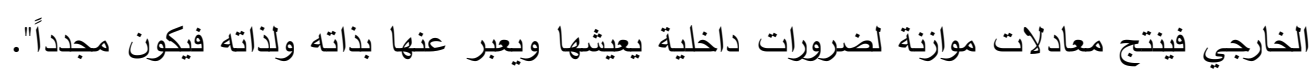

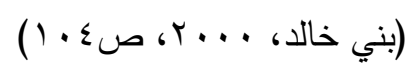

ومن ذلك تبدي الباحثة تفهماً في أن استلهام المصدم المعاصر للوحدات الزخرفية والحرف

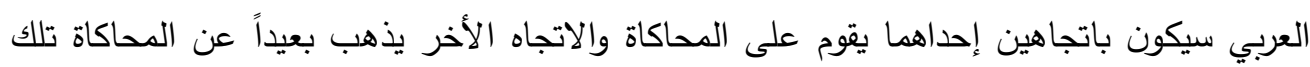

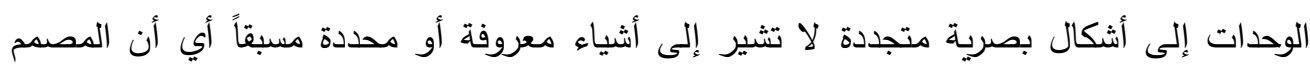
المعاصر سيقوم باعادة صياغة تلك الوحدات والحروف العربية بأنواعها ويضيف أليها أبعاداً جديدة البهاء

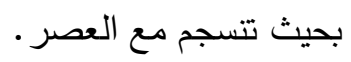

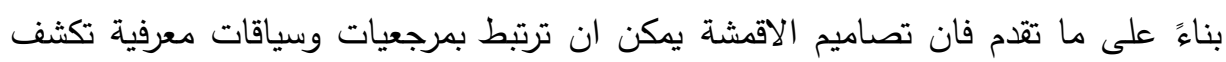

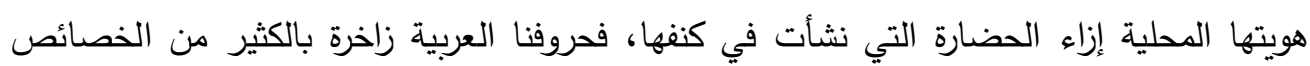

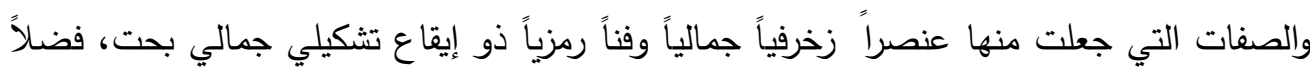

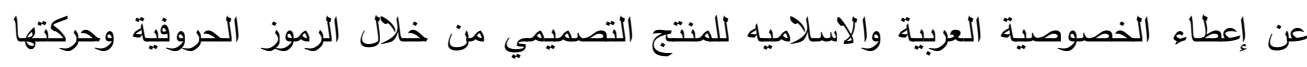

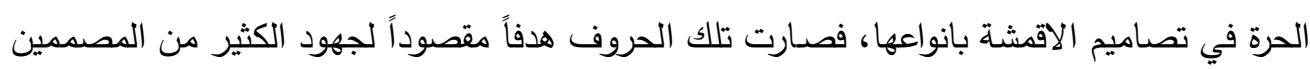

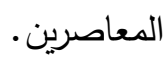

فمصمم الاقششة المعاصر من خلال بحثه في منطقه وضوح الهوية ارتد إلى منطقه الموروث

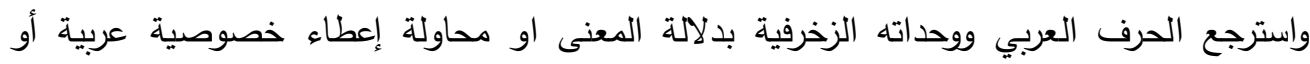
إسلامية للمنتج التصميمي، كما وجد فيه بنيه تجريدية جمالية صرفه أي استرجاع قيمه موروثة التهاء 
العـــــــد السابع وإلثلاثون



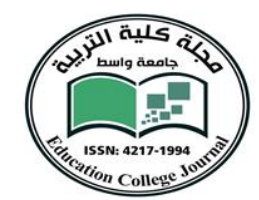

جامعة واسط

مجلـــة كليــــة التربيــــة وامسة

واستتطاقها بنظام حداثوي يشتغل في دائرة التعبير الجمالي بالدرجة الأساس، إلا إن الارتباط بالموروث العربي الإسلامي لا يعني الانقطاع عن مواكبة الميادين الجديدة ذات العلاقة المؤثرة في الحرف العربي ووحداته الزخرفية، لذا كان من الطبيعي أن تستقي من الماضي سمه شكليه قابله للاستخدام لتوائم الفكر والإحساس المعاصر - لمع إذ تؤكد أعمالهم الفنية المعاصرة فكرة حضارية غير منقطعة الجذور عما ابدعه الأوائل في



ولعل توظيف مصمموا الاقمشة بانواعها للوحدات الزخرفية والحرف العربي قد شكل سمة مميزة في تصاميمهح للاقشة، إذ تتوعت مجالات توظيفها وطرائق التعبير واساليب الاظهار، فلم يعد تدويناً ظاهرياً فقط وانما احتوى على العديد من المضامين والدلالات المستمدة من التراث الإسلامي توفي بصيخ جديدة ذات علاقة بشخصية المصمم وثقافته وأسلوبه، فانتج الوحدات الزخرفية والحرف العربي في ارتباطات جديدة حققت نوعاً من الابداع في تصاميم الاقمشة خاصة الموجه للنساء. فالوحدات الزخرفية والحرف العربي في الفن الإسلامي دلالة جمالية إضافة إلى دلالتهما التصورية والموضوعية، ولم تقتصر وظيفة الخطاط والمزخرف من الناحية الفنية على جمال الحرف الإسيك والوحدة الزخرفية فقط، بل اختيار النصوص والوحدات الزخرفية نفسها كان ذا مهمة تصويرية وجمالية خاصة في الكتابة والزخرفة على الأبنية والمساجد والملابس، فضلاً عن هناك جمال معنوي للحرف العربي والوحدات الزخرفية يمكن ان يدركه المشاهد ببصيرته قبل البصر وهذا الجمال المعنوي هو فوق القواعد الخطية والزخرفية أيضا، غير أن تتاسب الحروف والكلمات والزخارف تلك هي روح الجمال، لذلك لا يمكن ان يدرك هذا الجمال ويفهم إلا من خلال ارتقاء قدراته العقلية . (ذنون،

$$
\cdot(r)-r \cdot 0 \text { ( } 6 \text { ( } 1917
$$

لقد شهد فن تصميم الاقمشة بانواعها ومنها الموجه لفئة النساء مسارات تطويرية في نوع التصاميم معتمدة في ذلك على ما يستلهمه المصمم من مرجعيات ضاغطة تؤسس لافكاره التصميمية على وفق قواعد وضوابط جمالية تحقق اهداف المنتج التصميمي خاصة ما يرتبط بالموروث الحضاري بشكل والاسلامي بشكل خاص الذي اصبح مرجعاً مهماً يستلهم منه مفرداته التي اصبحت

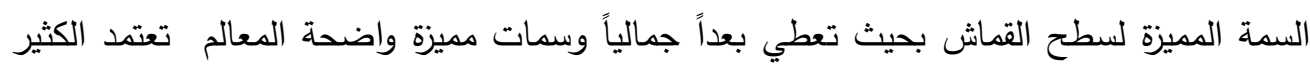
من الخطوط بعد تطويعها وتحويرها وتجريدها بتشكيل زخرفي يمكن ان يشكل بعداً جمالياً يرتبط

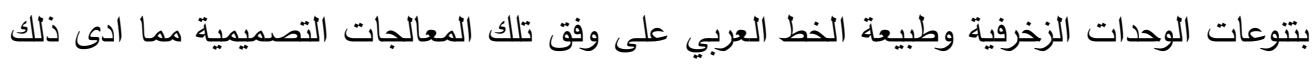


العـــــــد السابع والثلاثون

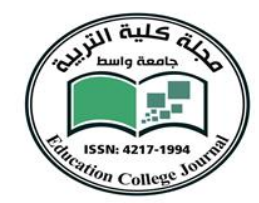

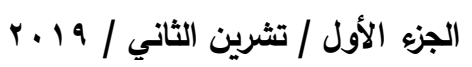

جامعة واسط

مجلـــة كليــــة التربيــــة

الى ظهور طبيعة جديدة للمظهر الخارجي للقماش والذي يعطي سمة الوضوح والمقرؤية، لصالح

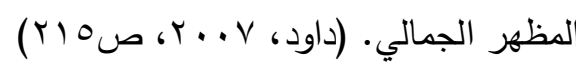

مما تقدم ترى (الباحثة) أن مصمح الاقشة النسائية يحاول في تصاميمه اعتماد الخصائص الجمالية والتشكيلية للوحدات الزخرفية والحرف العربي من خلال توظيفه لهما بما يمتلكانه من طاقات مضمرة وظاهرة تستطيع من تحقيق التصميم الفني والجمالي وإبرازه في تكوين تصميمي على سطح القماش يحمل مواصفات وخصائص جديدة تدل على ابتكارية المصمم.

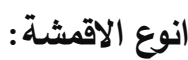

الأقششة الصناعيّة يتم إنتاج الأقشة الصناعيّة من أليافٍ مصنوعةٍ من موادٍ غير عضويّةٍ أو

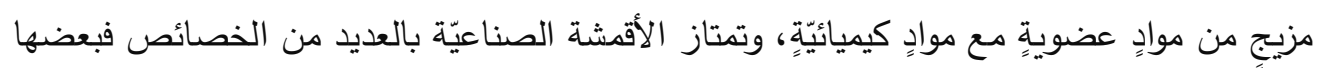
يكون خفيف الوزن وشفاف، والبعض الآخر سريع الجفاف وطارد للرطوبة، وهناك أنواع فاخرة جداً

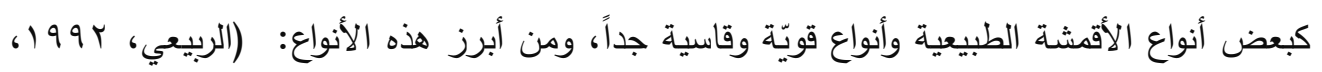
صن (rva

1- الأسيتات: هو قماشٌ فاخر وليّن، مصنوع من السليلوز ويتم الحصول عليه عن طريق إعادة بناء القطن أو لبّ الخشب، ويمتاز هذا القماش بمقاومته للانكماش والعفن. r- الشيفون: هو قماشُ خفيف وشفاف، يتم صناعته باستخدام الحرير أو الألياف الصناعيّة أو القطن أو النايلون أو البوليستر أو الرايون، يكثر استخدامه لفساتين الزفاف والسّهرة والحفلات والأوشحة.

r- الأكرليك: قماشٌ خفيف الوزن، وطويل الأمد، ويمتاز بسعره المنخفض، ويستخدم بشكلٍ رئيسيّ لصناعة الملابس كالقمصان وأزياء النساء الأخرى، بالإضافة إلى استخدامه في صناعة مقاعد الكراسي والأرائك.

ع- الأورغانزا: قماشُ رقيق، وخفيف، مصنوع من خيوط الديدان الحريريّة المنسوجة مع الألياف الصناعيّة كالنايلون والبولستر وللحصول على قماشٍ أكثر أناقةً يتم نسج الأورغانزا مع الحرير ، ومن أهم استخداماته في صناعة الحقائب بأشكالها. 
العــــــدد السابع والثلاثون

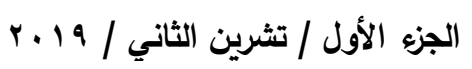

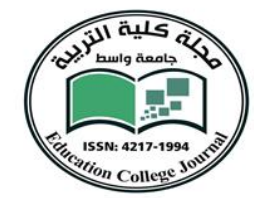

جامعة واسط

مجلـــة كليـــــة التربيــــة

ه- النايلون: قماشٌ مصنوع من مشتقات البترول، ذو وزنٍ خفيفٍ وأنسجةٍ قويةٍ ومرنة وطويلة الأمد، ويمتاز بسهولة تنظيفه وسعره المنخفص، ويستخدم النايلون بصناعة مجموعةٍ متنوعةٍ من المنتجات مثل الملابس، الحقائب، والأمتعة، والمحافظ.

צ- المخمل: هو قماشُ ناعمٌ وسلس، يمتاز بسهولة غسله وتجفيفه وسعره المنخفض، وتستخدم الأقمشة المخمليّة في صناعة العديد من المنتجات كالملابس بما في ذلك البناطيل والقدصان، بالإضافة إلى الشراشف والأغطية والستائر وغيرها. V- البوليستر : هو قماسٌ ناعمٌ وقوي، ويمتاز بمقاوته للانكماش، وغالباً يتم نسج البوليستر مع نوع قماش آخر ليصبح أكثر صلابةً من خلال نسجه مع الصوف مثلاً، ويستخدم البوليستر في صناعة الستائر ، وأغطية الأرضيات، والعتبات، والثراشف، والوسائد، والمواد العازلة. 1- التافتا: هو قماشُ حريريٌّ ناعم يمتاز باللدعان وعكسه للضوء والتموّج، وهو مصنوعٌ من الحرير الصناعيّ أو النايلون أو الرايون، ويستخدم في تصنيع الملابس النسائيّة. 9- الدنيم: هو قماشُ خفيف الوزن، قوي، ومريح، مصنوع من نسيجٍ قطنيّ طويل، ويُصبخ باللون الأزرق لصناعة بناطيل الجينز .

• 1- الرايون: هو قماشُ مصنوعٌ عن طريق إعادة تشكيل السليلوز، يمتاز بكفاءته العالية مقارنةً بأنواع الأقشة الأخرى كالتافتا، بالإضافة إلى سعره المنذفض، ويدخل في صناعة العديد من

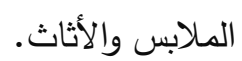

1ا - السباندكس: هو قماشُ مطاطيٌٌ ومرن، مقاوم للزيت والحرارة والتآكل والعرق، ويمتاز بقدرته على الاحتفاظ بشكله، ويستخدم في صناعة الملابس الداخليّة، بالإضافة إلى دعامات خراطيم المياه.

r ا - الجورجيت: هو قماشُ حريريٌّ شفاف خفيف الوزن، يمتاز بتوفير أقصى درجات الراحة وتكلفته القليلة، وهو مصنوع من الحرير أو البوليستر ، ويكثر استخدامه في صناعة الأزياء. 
العـــــــد السابع والثلاثون

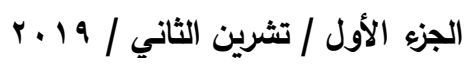

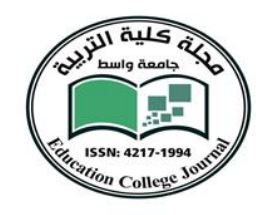

جامعة واسط

rا - الفيسكوز : هو قماشُ يستخدم في عمليّة عزل الأقشة وصناعة الملابس الداخليّة، وجوارب

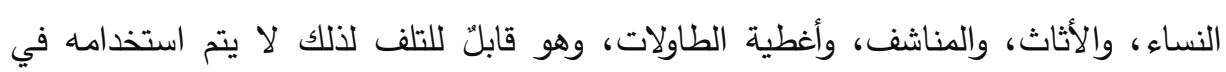

$$
\text { تصنيع المنتجات الصلبة. }
$$

ـ ا - اليّتان: هو قماشُ لامعٌ وبرّاق، ويمتاز بنعومة سطحه.

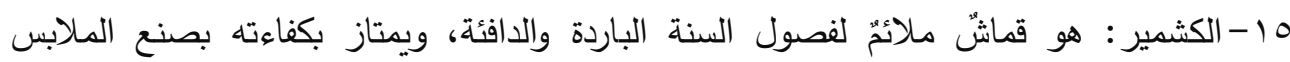

$$
\text { الجاهزة. }
$$

17 - الدانتيل: هو قماشُ راقي ذائع الصّيت، ويستخدم في صناعة الأزياء الراقية وفساتين الزفاف

$$
\text { والملابس الجاهزة، ويتوفر بألوانٍ عدة كالأبيض والأسود والأحمر . }
$$

V V ا التّول: يستخدم هذا القماش في صناعة فساتين الزفاف والأزياء الفخمة.

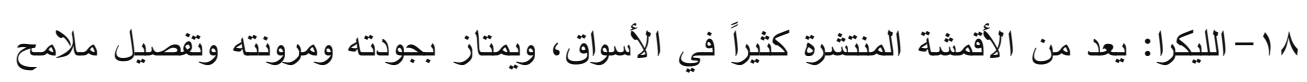

$$
\text { الجسد عند ارتدائه. }
$$

19 - الكروشيه: قماشُ يستخدم في صناعة السراويل القصيرة والفساتين.

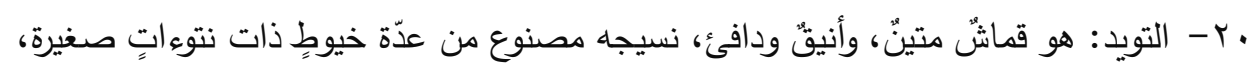

ويمتاز بطابع كلاسيكيّ ريفيّ، ويستخدم بصنع التتانير، والمعاطف، والأحذية، والحقائب.

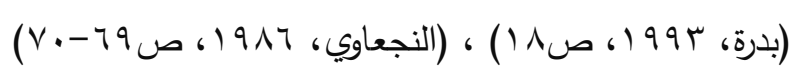

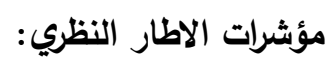

ا. ان عملية التواصل مع الموروث ليس بالأمر اليسير لاى الفنان او المصمم المعاصر على لئى



$$
\text { روح العصر • }
$$

r. عملية توظيف الوحدات الزخرفية والحرف العربي في تصاميم الاقمشة النسائية، لذلك يمكن استلهام المصمم المعاصر لإحدى الجوانب المهمة من ذلك الموروث الحضاري لها له من قيمة فكرية واجتماعية. 
العـــــــد السابع والثلاثون

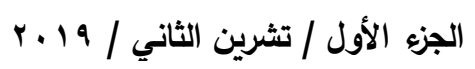

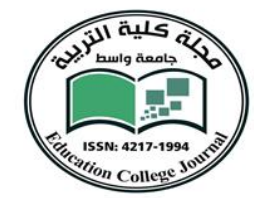

جامعة واسط

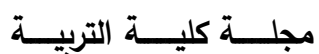

r. لابد ان يعتمد مصمم الاقشة الموجهة للفئة العمرية مرجعيات حضارية وشعبية تحمل خصوصية البيئة المحلية للمجتمع كونها تشكل عملية تفاعل ومناطق جذب للمتلقي. ع. تعد المفردات التصميمية من الركائز الاساسية التي يعتمدها مصمم الاقمشة الموجهة للنساء كونها تستتبط منها ما يتلائم مع طبيعتها، لذلك فان الاشكال التي تعتمدها في التصميم يمكن ان تشكل عمقاً حضارياً وتاريخياً واجتماعياً وثقافياً متميزاً يتناسب مع طبيعة المجتمع العراقي. ه. ان وظائف الثكل وخصائصه قد اعطت مجموعة دلالات تعبر عن موضوع تصاميم الاقشة الموجهة للفئة المستهدفة من حيث دلالاتها الايقونية والاشارية والرمزية التي تتلائم مع البيئة العراقية. T. . V-تعد المفردات التصميمية الركيزة الاساسية التي يتم من خلالها تصميم الاقشة الموجهة للفئة

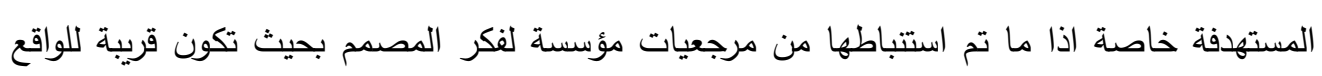
الذي يعيشها المستخدم.

\section{الفصل الثالث / منهجية البحث واجراء اته}

اعتمدت الباحثة المنهج الوصفي التحليلي في تصميم اجراءات بحثها كونها اكثر المناهج العمية ملائمة لتحقيق هدف البحث.

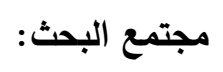

يتضمن البحث الحالي دراسة وتحليل تصاميم اقشة النساء ضمن الواقع الميداني والاستطلاعي التي حصلت من خلالها الباحثة على مجموعة تصاميم تم عرضها في الاسواق المحلية لمدينة بغداد لغرض تحقيق هدفا البحث، اذ تم حصر (ro) أنموذجاً تصميمياً لاقشة الازياء النسائية.

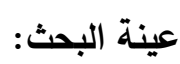

تم اختيار (ع ) نماذج سائدة في الاسواق المحلية وهي من الاقمشة المستوردة والموجهة لفئة

$$
\text { النساء تمثلت بنسبة (1\%). }
$$
اداة البحث:

قامت الباحثة بناء استمارة تحليل محتوى نماذج العينة بناءً على ما اسفر عنه الاطار النظري من مؤشرات متضمنة محاور اصبحت فقرات اساسية خاصة بتصاميم اقمشة الازياء النسائية والمتعلقة بمتطلبات البحث محققاً بذلك هدف البحث. مؤرات 
العــــــد السابع والثلاثون

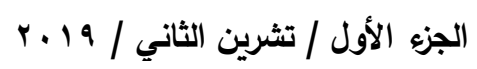

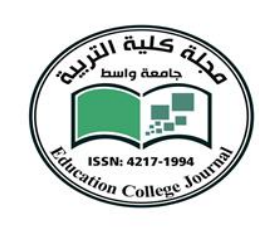

جامعة واسط

مجلـــة كليــــة التربيــــة

صدق الاداة: - (20

تم عرض استمارة التحليل على مجموعة من المحكمين" في تخصصات التصميم الطباعي وتصميم الاقمشة لغرض التعرف على صلاحية مكوناتها من خلال عرض محتوى هذه الاستمارة ونماذج العينة عليهم للوصول الى صدلاحيتها في تحليل هذه النماذج. الاستمارة النهائية لتحليل العينات

\begin{tabular}{|c|c|c|c|c|}
\hline \multicolumn{3}{|c|}{ تظهر بلدرجة: } & \multirow[t]{2}{*}{ المحاور } & \multirow[t]{2}{*}{ محاور الاداة } \\
\hline ل الغهر & الى حد ما & كبيرة & & \\
\hline & & & الشكل & \multirow[t]{2}{*}{ ا -الوصف البصري } \\
\hline & & & 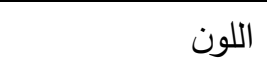 & \\
\hline & & & بيئة محلية & \multirow[t]{2}{*}{ r-المرجعيات الضاغطة } \\
\hline & & & بيئة اجنبية & \\
\hline & & &  & r- الاستخدام الوظيفي للقماش \\
\hline & & & طبيعية & \multirow[t]{2}{*}{ ع -نوع الخامة المستعملة } \\
\hline & & & صناعية & \\
\hline & & & واقعية & \multirow{3}{*}{ ه-اسلوب ت مغنيذ } \\
\hline & & & تجريدية & \\
\hline & & & محورة & \\
\hline
\end{tabular}

" استعانت الباحثة بمجموعة من المحكمين هم:

ا - أ.د. فاتن علي العامري، قسم التصميم - فرع الاقمشة / كلية الفنون الجميلة.

r-أ.م.د. هند محمد سحاب، قسم التصميم - فرع الاقمشة / كلية الفنون الجميلة.

ץ-أ.م.د. معتز عناد غزوان، قسم التصميم - فرع الطباعي / كلية الفنون الجميلة.

ع - م.د. مروان توفيق، قسم التربية الاسرية والمهن الفنية - الجامعة المستتصرية / كلية التربية

الاساسية.

ه- م.د. نبيل احمد فؤاد، قسم التصميم - فرع الطباعي / كلية الفنون الجميلة. 
العـــــــد السابع وإلثلاثون

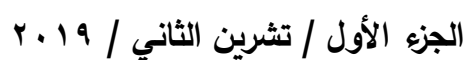

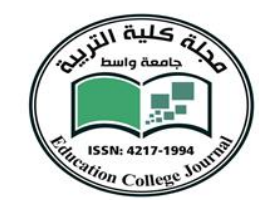

جامعة واسط

مجلـــة كليـــــة التربيــــة وسيطة

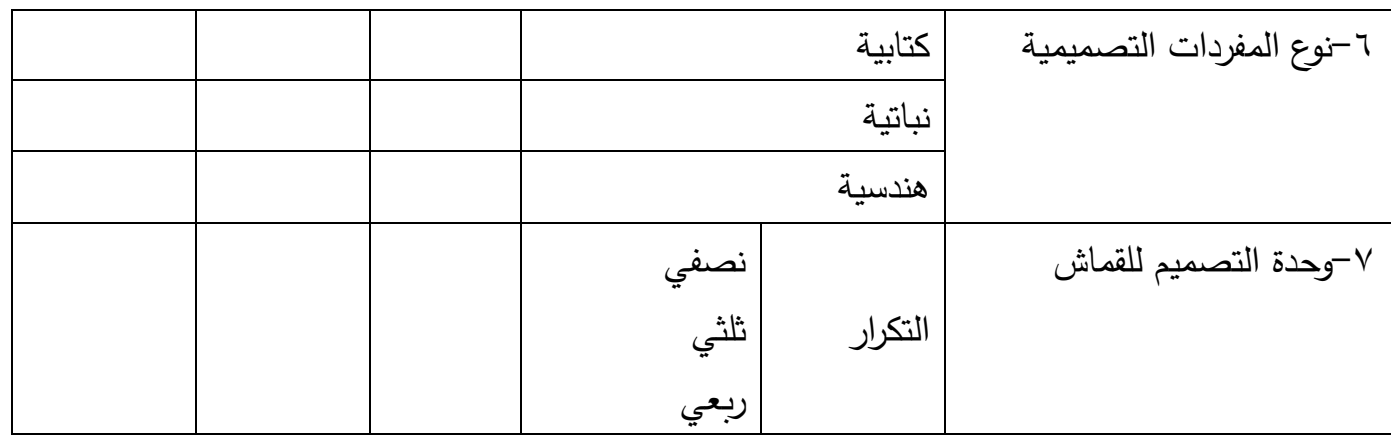

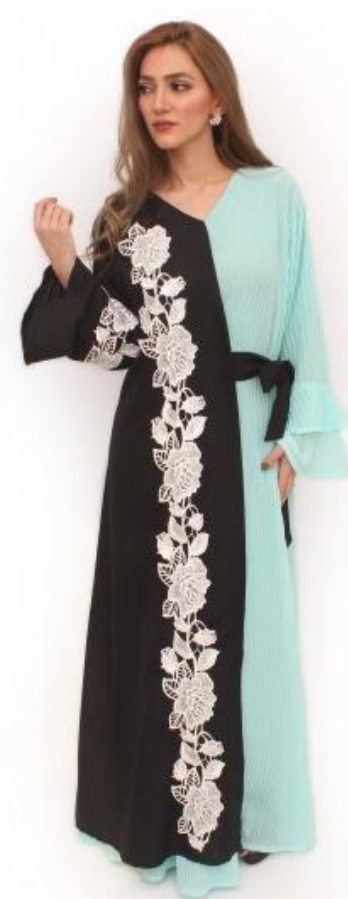

تحليل العينات

أنموذج (1)

الخامة: قطني. الالوان المستخدمة: اسود + سمائي + زخرفة نباتية بيضاء الاستخدام الوظيفي: اقشة ملابس المولس

\section{1-الوصف البصري:}

يتكون التصميم من قطعتين احدهما ذات لون سمائي والاخر دات لون اسود تتوشح بشريط زخرفي نباتي، اذ تم صنع هذا التصميم من خامة الجورجيت هو قماشٌ حريريٌّ شفاف خفيف الوزن، يمتاز بتوفير أقصى درجات الراحة وتكلفته القليلة، وهو مصنوع من الحرير أو هون هوني البوليستر ، ويكثر استخدامه في صناعة الأزياء. 
العـــــــد السابع وإلثلاثون

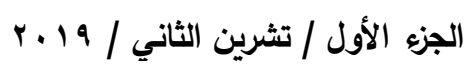

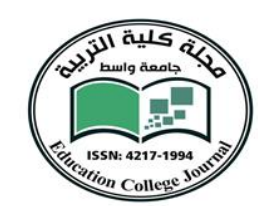

\section{جامعة واسط}

مجلـــة كليــــة التربيــــة

\section{r-المرجعيات الضاغطة:}

من خلال ملاحظة مفردات التصميم يمكن ان تحيلنا الى انها مستعارة من البيئة الواقعية للمستخدم، اذ ان صورة هذا الزي تتوشح بشريط زخرفي نباتي له دلالات بيئية محلية تم تجريدها وتحويرها على شكل ايقونة بصرية تحمل اللون الابيض لتشكل ايقونة جاذبة ومثيرة للمنظومة البصرية التي تتمتع بها المراة. ب-الاستخدام الوظيفي للقماش:

يستخدم هذا التصميم لازياء المرأة كونه يتتاسب مع الفئة المستهدفة.

$$
\text { ع -نوع الخامة: }
$$

تتمثل خامة القماش بكونها مصنوعة من خامة الجورجيت لتتلائم مع جسم المراة والتي تتمتع خامتها بالمرونة والحركة.

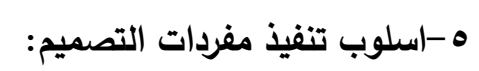

يتميز تصميم القماش بكونه يعتمد مفردات نباتية واقعية تم تجريدها الى ايقونات نباتية محورة ذات اتجاه واحد لكي تتفاعل معها المرأة ولا تسمح بتشتت بصرها باتجاهات مختلفة.

$$
\text { צ-نوع المفردات: }
$$

تتميز مفردات هذا التصميم بكونها زخرفة نباتية مجردة.

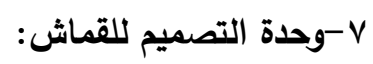

تتميز وحدة التصميم بانها تكرار للزخرفة النباتية المجردة لتشكل ايقونة نباتية ذات لون ابيض

$$
\text { تستند الى ارضية سوداء بحيث شكلت انسجام لوني عالي. }
$$


العـــــــد السابع والثلاثون

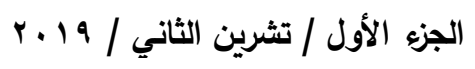



جامعة واسط

مجلـــة كليـــة التربيــة

\author{
انموذج (r) \\ الخامة: خامة الاسيتات \\ الالوان السستخدمة: ابيض \\ الاستخدام الوظيفي: اقمشة ازياء
}

1-الوصف البصري:

امتلكت مفردات التصميم هويتها من خلال استعارة رمزية لشخصية مطربة الغناء العربي السيدة



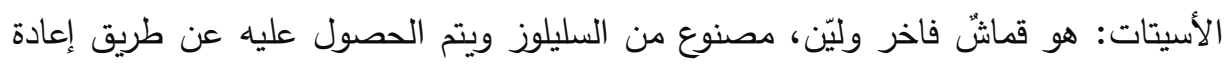

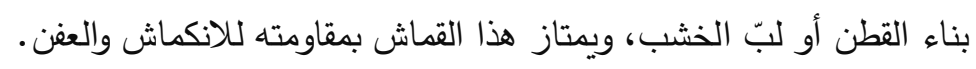

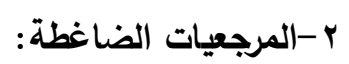

تعود مفردات تصميم سطح القماش الى استعارة ايقونة مطربة الغناء العربي السيدة ام كلثوم من

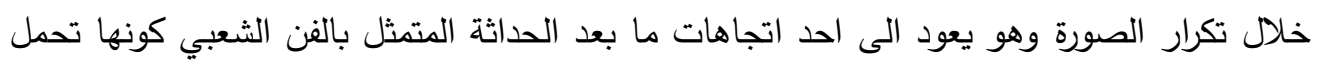

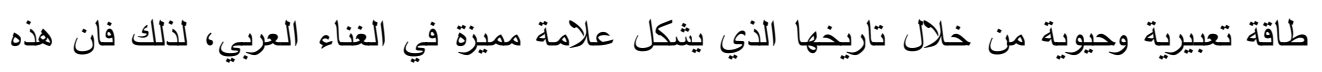

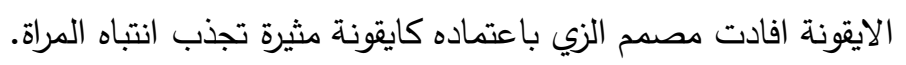

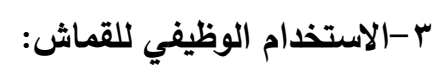

يستخدم هذا التصميم لتصميم الازياء والملابس الموجهة للمراة كونه يتتاسب مع الذوق العام.

$$
\text { ع -نوع الخامة: }
$$

تتمثل خامة القماش بكونها مصنوعة من خامة الاسيتات لتتلائم مع طبيعة جسم المراة كونها تتميز هذه الخامة بالمرونة والحركة العالية.

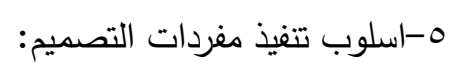


العـــــــد السابع وإلثلاثون



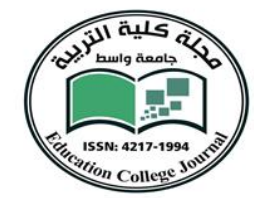

\section{جامعة واسط}

مجلـــة كليـــــة التربيــــة

يتميز تصميم القماش بكونه يعتمد ايقونة لمطربة الغناء العربي السيدة ام كلثوم تم تحويرها

وتصميميها باتجاه واحد وبحركة واحدة لكي تتفاعل معها المراة التي ترتدي هذا الزي بحيث لا تسمح

$$
\text { بتشتت بصرها باتجاهات مختلفة. }
$$

تتميز مفردات هذا التصميم بكونها ايقونة شعبية متداولة في المجتمع العربي.

\section{V-وحدة التصميم للقماش:}

تتميز وحدة التصميم بانها تكرار لايقونة مطربة الغناء العربي السيدة ام كلثوم صممت بشكل مبسط متكرر وبالوانها التي تظهر على سطح الخامة، كذلك شكل اللونين الابيض والسمائي على مبدأ الشكل والارضية.

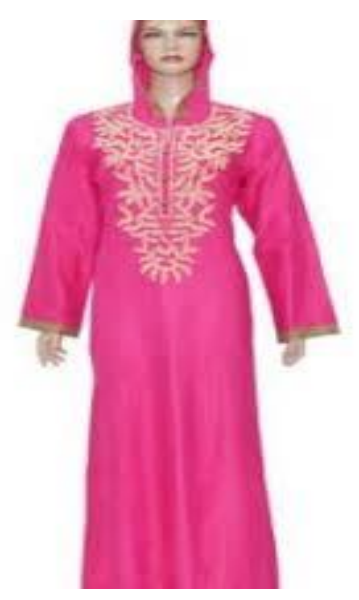

انموذج (r)

الخامة: خامة التافتا

الالوان المستخدمة: الوردي + زخرفة هندسية

الاستخدام الوظيفي: اقمشة ملابس

1-الوصف البصري:

امتلكت مفردات التصميم هويتها من خلال استعارة لايقونية هندسية شكلت حلية زخرفية تتميز بخطوطها المتتوعة، كما ان خامتها صنعت من خامة التافتا وهو قماشٌ حريريٌّ ناعم يمتاز باللمعان وعكسه للضوء والتموّج، وهو مصنوعٌ من الحرير الصناعيّ أو النايلون أو الرايون، ويستخدم في تصنيع الملابس النسائيّة. 
العـــــــد السابع والثلاثون

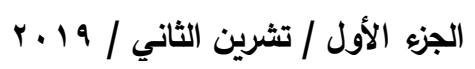

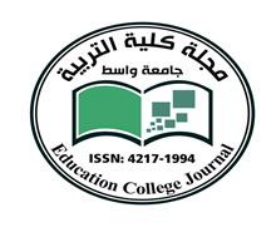

جامعة واسط مجلـــة كليــــة التربيــــة

\section{r-المرجعيات الضاغطة:}

تعود مفردات تصميم القماش الى استعارة ايقونة هندسية مجردة ومحورة على شكل حلية زخرفية استمدت مكوناتها لتتجد بشكل ايقونات متتوعة منها قرص الشمس لتحمل طاقة تعبيرية وحيوية من خلال حركاتها الديناميكية التي افادت مصمم القماش باعتمادها كايقونة مثيرة تجذب انتباه المراة. ب-الاستخدام الوظيفي للقماش:

يستخدم هذا التصميم لازياء وملابس المراة كونه يتتاسب مع اوقات الراحة واستقبال الضيوف. ع -نوع الخامةة:

تتمثل خامة القماش بكونها مصنوعة من خامة التافتا لتتلائم مع طبيعة جسم المراة وحركتها ومرونتها.

ه-اسلوب تنفيذ مفردات التصميم:

يتميز تصميم القماش بكونه يعتمد ايقونة هندسية مجردة ومحورة صممت باتجاهات مختلفة مما شكلت تتوع في الحركة لكي تتفاعل معها المراة بحيث تسمح بتشتت بصرها باتجاهات مختلفة.

ج-نوع المفردات:

تتميز مفردات هذا التصميم بكونها ايقونة هنسية مجردة.

V-وحدة التصميم للقماش:

تتميز وحدة التصميم بانها تكرار لايقونة هندسية مجردة صممت بشكل مبسط متكرر وبلونها



الذهبي.

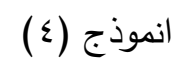

الخامة: الشيفون.

الالوان المستخدمة: الوان مختلفة

الاستخدام الوظيفي: اقمشة الازياء النسائية 


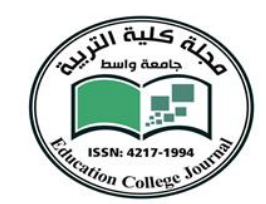

العـــــــد السابع والثلاثون

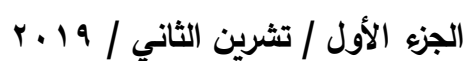

جامعة واسط

مجلـــة كليــــة التربيــــة

\section{1-الوصف البصري:}

امتلكت مفردات التصميم هويتها من خلال الوحدة الزخرفية التي صممت على شكل حلية تتللى على صدر المستخدم او في الاكمام بطريقة منتظمة، اذ صمح النموذج باستعمال خامة الثيفون والتي هي نوع من القماشُ الخفيف والثفاف، والذي يتم صناعته باستخدام الحرير أو الألياف الصناعيّة أو القطن أو النايلون أو البوليستر أو الرايون، يكثر استخدامه لفساتين الزفاف والسّهرة والحفلات والأوشحة والكلابيات.



يعود شكل الوحدة الزخرفية في التصميم الى استعارة مفردات متنوعة منها نباتية واخرى تشبه قرص الشمس او اجنحة طيور ، اما الثكل العام للتصميم فانه صمم بهيئة ورقة نباتية يمكن ان تشكل طاقة تعبيرية مثيرة تجذب انتباه المستخدم مما ولد ذلك قيمة جمالية. r-الاستخدام الوظيفي للقماش:

يستخدم هذا التصميم لازياء وملابس النساء كونه يتناسب مع حاجاتهن.

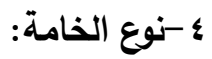

تتمثل خامة القماش بكونها مصنوعة من الثيفون الذي يتلائم مع طبيعة جسم المراة وحركتها ومرونتها مع كونه يحافظ على شكله العام. ه-اسلوب تنفيذ مفردات التصميم:

يتميز تصميم القماش بكونه يعتمد على استعارة الوحدة الزخرفية المتنوعة.

$$
\text { 7-نوع المفردات: }
$$

تتميز مفردات هذا التصميم بكونها ايقونة زخرفية متتوعة ما بين نباتية وهندسية مجردة تعتمد الحجم واللون والاتجاه.

\section{V-وحدة التصميم للقماش: - V}

تتميز الوحدة الزخرفية للتصميم بانها تكرار لايقونة متتوعة صممت بشكل مبسط متكرر وبالوانها التي تظهر فيه على سطح القماش. 
العـــــــد السابع والثلاثون



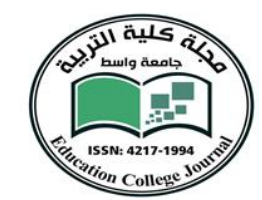

\section{جامعة واسط}

مجلـــة كليـــة التربيــة

\section{الفصل الرابع / عرض النتائج ومناقشتها \\ بناءً على تحليل نماذج العينة تعرض الباحثة النتائج الاتية:-}

1-الوصف البصري: تباينت مفردات الوحدات الزخرفية لتصاميم نماذج العينة ما بين بصرية نباتية التهاتية


ان تجذب انتباه المستخدم (المراة) كونها مستقاة من الواقع البيئي. ץ-المرجعيات الضاغطة: ان اعتماد المصمم على مفردات من الواقع البيئي للمستخدم تم تجريدها

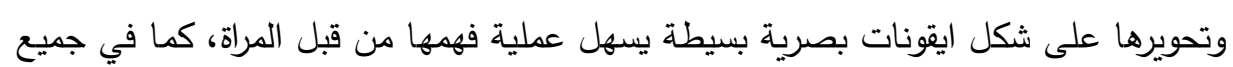

$$
\text { نماذج العينة. }
$$

r-الاستخدام الوظيفي للقماش: تباينت عملية استخدام القماش بحسب نوع خامته ووظيفته الموجه للمراة فمنها يتعلق بالازياء او الملابس.

ع-نوع الخامة: ان اغلب الاقشة المصممة تعتمد على خامة القطن الاسيتات - الثيفون - التافتاالجورجيت لتتلائم مع جسم المراة وحركتها وتميزها بالمرونة كما في جميع العينات. ه-اسلوب تتفيذ القماش: ان اعتماد القماش على مفردات مصنوعة من من واقع المستخدم وتجريدها

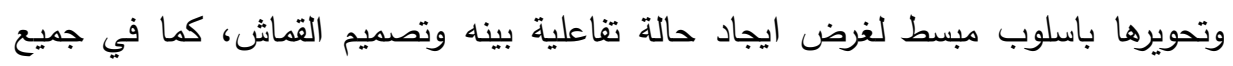
النماذج.

4-وحدة تصميم القماش: تميزت وحدة التصميم في القماش بتكرار المفردات وتبسيطها بالوانها واحجامها من اجل جذب انتباه المستخدم.

V-المقترحات التصميمية: اقترحت الباحثة نماذج تصميمية تتلائم مع طبيعة المستخدم (المراة) والبيئة التي تعيشها. 
العـــــــد السابع والثلاثون

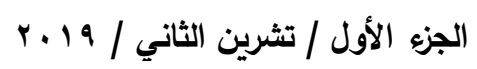

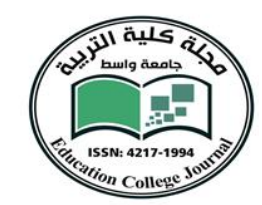

on College 30

\section{جامعة واسط}

مجلـــة كليـــة التربيــة

الاستنتاجات:

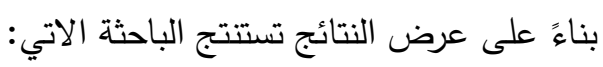

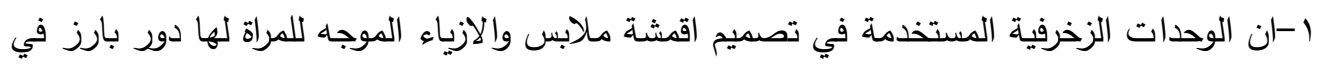

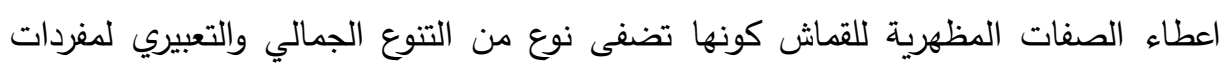

$$
\text { التصميم. }
$$

r-ان الالوان التي وظفها مصمم الاقمشة لعبت دوراً اساسياً في ابراز جمالية الوحدات الزخرفية والهندية التصميمية للقماش مما حققت نوعاً من الابعاد الرمزية والجمالية والوظيفية.

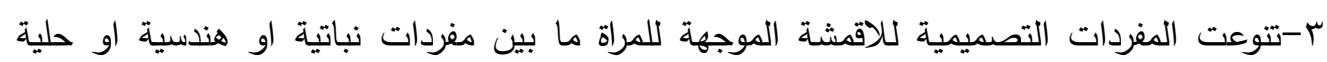
زخرفية مما شكل ذلك ابعادً دلالية وجمالية في الوقت نفسية.

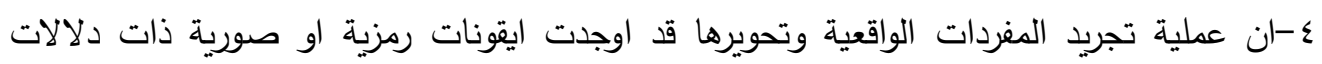
اشارية يمكن ان يتفاعل معها المستخدم عند الاستخدام.

ه-يظهر ان جميع نماذج العينة قد درست تصاميمها بشكل سليم لغرض مخاطبة ذائقة المراة وتنمية وعيه من خلال استعارة الايقونات المختلفة من الواقع البيئي له.

\section{التوصيات:}

بناءً على الاستتناجات توصي الباحثة بالاتي:

ا-ضرورة اختيار الخامات المناسبة لاقمشة ملابس الاطفال لكي لكئه بتانلائم مع طبيعة جسمه وحركته

ومرونته.

r-ضرورة توظيف عناصر ومفردات لتصاميم اقشة الاطفال مستمدة من الواقع البيئي تكون مبسطة وسهلة الفهم والادراك من قبل الطفل.

r-الابتعاد عن الرموز والاشارات والصور الكتابية الاجنبية عند تصميم الاقشة الموجه للطفل لالهانها

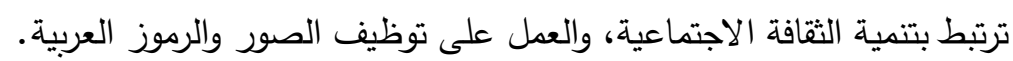

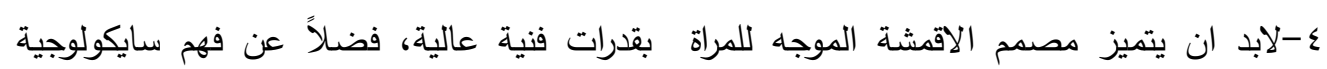

$$
\text { المستخدم. }
$$

نماذج مقترحة من تصميم الباحثة

بناءً على ما تقدم تقترح الباحثة التصاميم الاتية 
العــــــد السابع والثلاثون

الجزء الأول / تثرين الثاني / 9 / 19
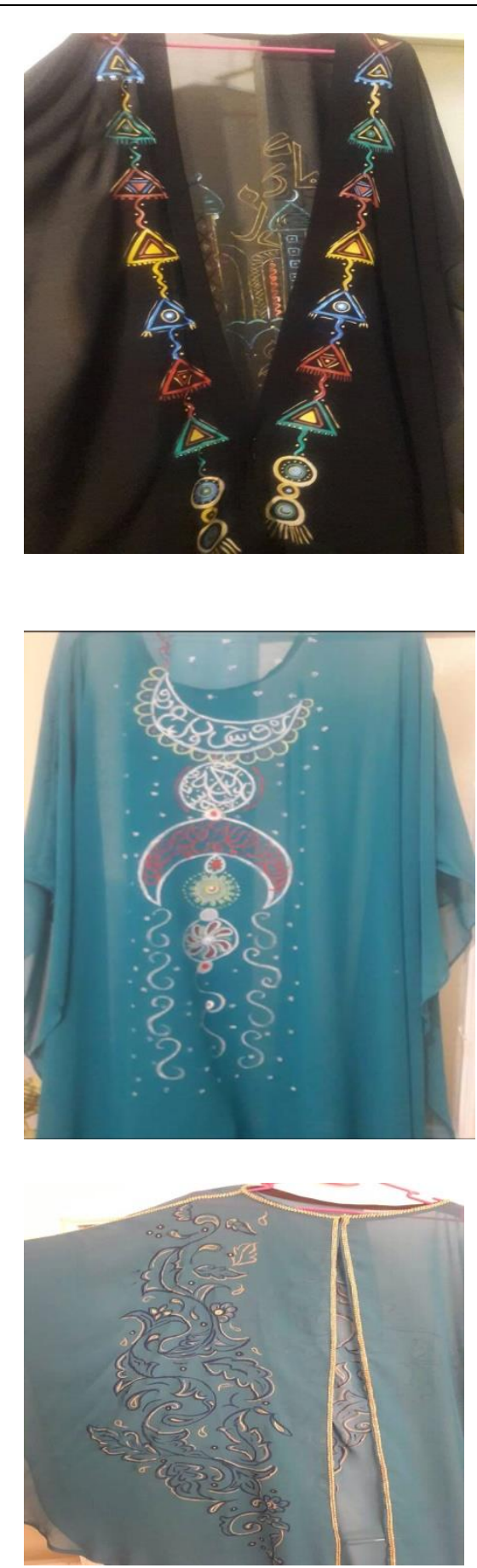

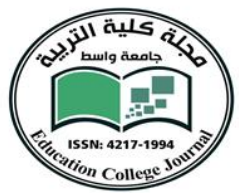

جامعة واسط مجلــــة كليـــــة التربيـــــة
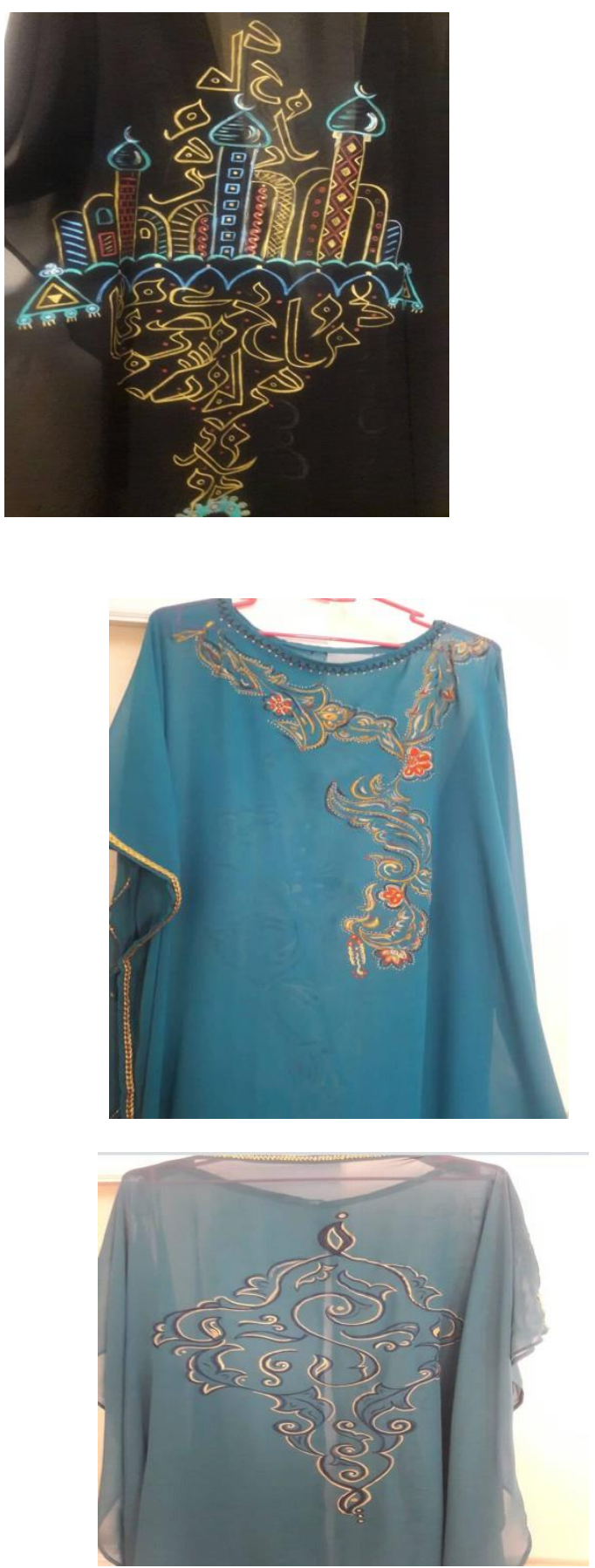


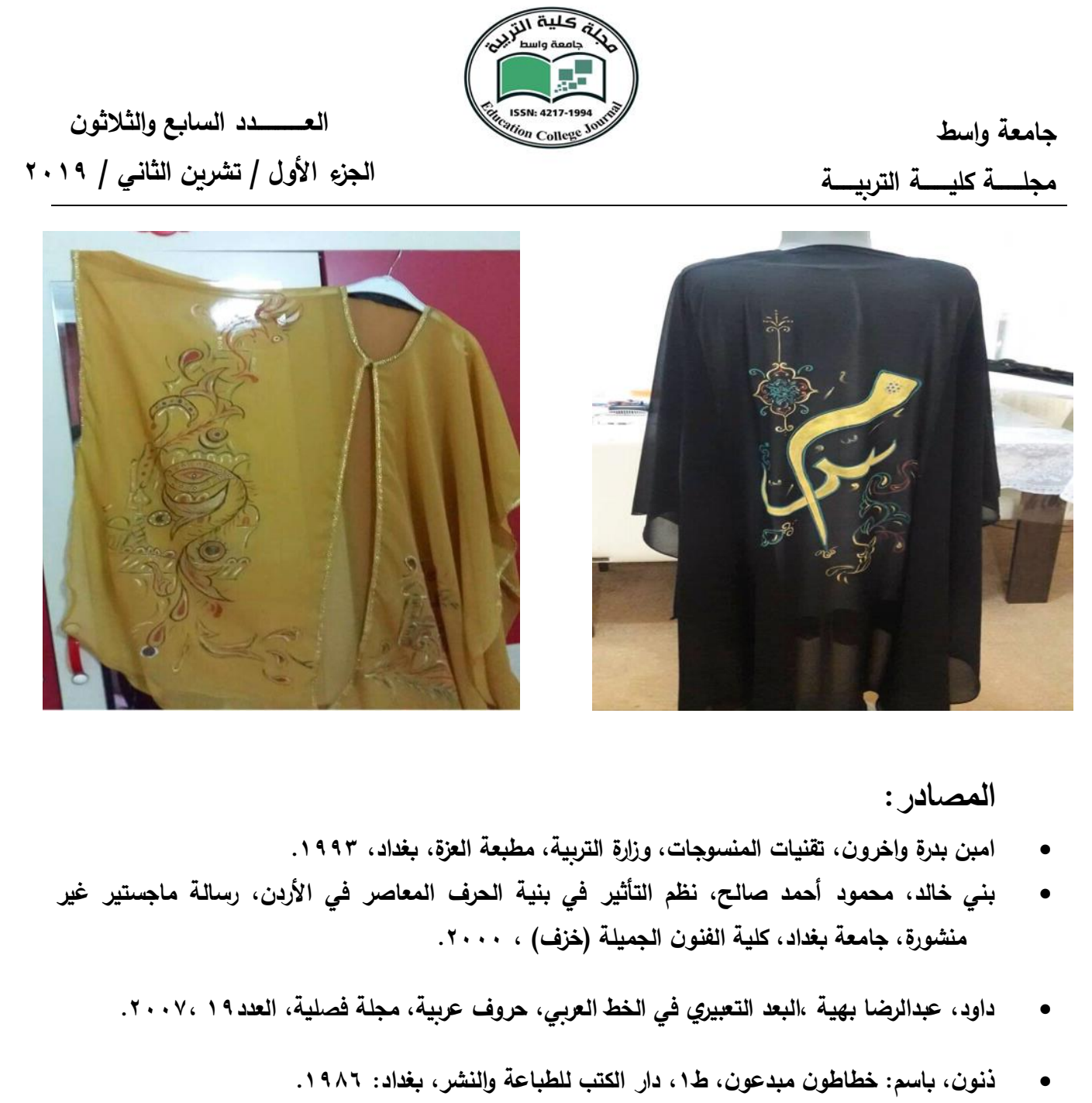

• الربيعي، ناصر حسين واخرون، خواص المواد النسيجية، هيئة المعاهد الفنية، دار الكتب للطباعة والنشر،

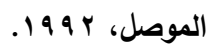

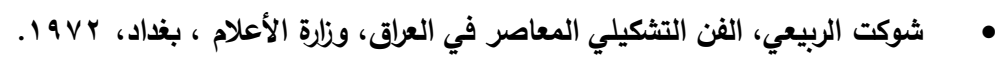

• غزوان، عناد، الناقد العربي المعاصر والموروث النقدي، بحث إلى المؤتمر الخامس عثر للاتحاد العام للأدباء

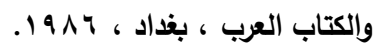

• النجعاوي، احمد فؤاد، تكنولوجيا صباغة طباعة وتجهيز الاقمشة القطنية، منشأة المعارف، الاسكندرية، 4919

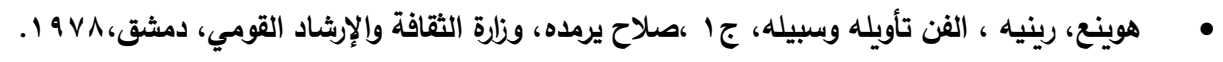

